\title{
Changes of Phytosterols, Rheology, Antioxidant Activity and Emulsion Stability of Salad Dressing with Cocoa Butter During Storage
}

\author{
Roiaini Mohamad', \\ Baizura Aya Putri Agus ${ }^{1}$ \\ and Norhayati Hussain 1,2* \\ 'Department of Food Technology, \\ Faculty of Food Science and \\ Technology, Universiti Putra Malaysia, \\ 43400 Serdang, Selangor, Malaysia \\ ${ }^{2}$ Halal Products Research Institute, \\ Putra Infoport, Universiti Putra \\ Malaysia, Selangor, Malaysia
}

Received: 31 January 2018 Accepted: 22 January 2019

\section{(c) (i) (9)}

*Corresponding author:

Phone: +60389468536

Fax: +60389423552

E-mail: aryatihussain@upm.edu.my

\section{SUMMARY}

Addition of phytosterols and antioxidants to food may provide additional health benefits to consumers. Their stability in a food matrix may decrease during storage. Therefore, the objectives of this study are to formulate a salad dressing with cocoa butter and determine its phytosterol stability, antioxidant activity and physicochemical properties during storage. The cocoa butter was extracted using a supercritical $\mathrm{CO}_{2}$ extraction (green technology) and added to the formulated salad dressing (containing different ratios of cocoa butter and soybean oil). The salad dressing with $30 \%$ cocoa butter (the most stable emulsion) was selected for storage study at 4 and $30^{\circ} \mathrm{C}$. However, values of physicochemical parameters and mass fractions of phytosterols, total phenolic compounds (determined using Folin-Ciocalteu reagent) and 2,2-diphenyl-1-picrylhydrazyl (DPPH) in the salad dressing with $30 \%$ cocoa butter decreased during storage (from day 0 to 28 ) and increased with the temperature increase, probably due to the oxidation of oil. Thus, the most desirable storage temperature for salad dressing was $4{ }^{\circ} \mathrm{C}$. An excellent stability of the salad dressing with $30 \%$ cocoa butter at different storage temperatures for 28 days offers a potential application in food industries for production of salad dressing with cocoa butter enriched with phytosterols.

Key words: phytosterols, antioxidant activity, cocoa butter, salad dressing, soybean oil, physicochemical characteristics

\section{INTRODUCTION}

Phytosterols are present in vegetable oil at about $0.1-0.9 \mathrm{~g} / 100 \mathrm{~g}$ and have a chemical structure similar to cholesterol (1). They exist in free and esterified forms (200-300 mg per $100 \mathrm{~g}$ fat) in cocoa beans. Most abundantly found are $\beta$-sitosterol and stigmasterol, amounting to 59 and $22 \%$ of total phytosterols in cocoa beans, respectively (2). Natural compounds such as phytosterols or tocopherols, as well as their antioxidant potential, are of increasing interest today due to their health benefits. Many researchers have conducted research on the addition of plant sterols to a wide range of foods such as margarine, yogurt and salad dressing (3). Ntanios et al. (4) stated that daily consumption of a spread enriched with $1.8 \mathrm{~g}$ phytosterol esters effectively reduces total plasma cholesterol, low-density lipoprotein cholesterol, plasma apolipoprotein B and remnant-like particle cholesterol. The rheology of salad dressing has also been investigated by several authors due to the importance of finding an adequate formulation, process conditions and quality control (5). However, no one has studied the effects of phytosterols from cocoa butter on the properties of salad dressing.

Oxidation can occur in phytosterols where sites of oxygen attack are $\mathrm{C} 7$ and tertiary carbon atoms in the side chain. It was found that the presence of an additional double bond at the side chain may have both protective and stimulating effect during phytosterol oxidation (6). The oxidative stability of lipid compounds, for example the opposition to oxidation and the formation of oxidation products, is crucial for the foods enriched with phytosterols/ stanols (7). Oxidation reactions in phytosterols are more significant at temperatures above $100^{\circ} \mathrm{C}$. However, at lower temperatures, the significance of oxidation reactions increases 
with time. Although phytosterols and stanols are stable under general food processing conditions, the oxidative stability of new phytosterol-enriched foods must be established due to complex interactions among other food constituents (7).

The storage of the samples for determination of phytosterols must be handled with care since phytosterols are unstable components. Jekel et al. (8) established that after 6 weeks of storage, the content of phytosterols is reduced and they are more stable in a non-lyophilised material (homogenised diet) stored at $-20^{\circ} \mathrm{C}$ than in lyophilised material stored at $4{ }^{\circ} \mathrm{C}$. Thus, the objective of this research is to determine the composition of phytosterols, antioxidant and physicochemical properties of newly developed salad dressing with cocoa butter compared to control (0\%) and commercial salad dressing during storage.

\section{MATERIALS AND METHODS}

\section{Materials}

Dried cocoa beans were purchased from Lembaga Koko Malaysia (Jengka, Malaysia). Cocoa shells were removed manually from the beans and nibs were smashed with a mortar and pestle to approx. $<1 \mathrm{~mm}$ in size. Cocoa butter used in this study was extracted from the nibs using supercritical $\mathrm{CO}_{2}$ extraction and ethanol. For supercritical extraction we used model PU-1580 Intelligent HPLC pump (Jasco Corporation, Tokyo, Japan). A back pressure regulator model BP-1580-81 (Jasco Corporation) controlled the extraction pressure and separation. Approximately $20 \mathrm{~g}$ of cocoa nibs were loaded into $50-\mathrm{mL}$ extraction vessel. Extraction with ethanol occurred at $78^{\circ} \mathrm{C}, 35 \mathrm{MPa}$ pressure and a flow rate of $2 \mathrm{~mL} / \mathrm{min}$. The brand of commercial salad dressing was Lady's Choice MayoLite (Unilever, Kuala Lumpur, Malaysia). The ingredients include soybean oil, egg, modifed starch, sugar, salt, vinegar, lemon juice, potassium sorbate, phosphoric acid, citric acid, calcium disodium EDTA and edible gum. Newly formulated dressing was composed of soybean oil (Soya Lite, Subang Jaya, Malaysia), lemon juice, egg yolk, sodium benzoate, vinegar, sugar, salt, and xanthan and Arabic gum (both from Markaids Sdn. Bhd., Selangor, Malaysia).

\section{Chemicals and standards}

High-performance liquid chromatography (HPLC) grade ethanol, methanol, diethyl ether and ethyl acetate were purchased from Fisher Scientific (Loughborough, UK). Analytical grade anhydrous sodium sulfate, sodium hydrogen carbonate, potassium hydroxide and sodium carbonate were purchased from Fisher Scientific, Folin-Ciocalteu reagent, Trolox, gallic acid and standards such as 5-a cholestane, stigmasterol, $\beta$-sitosterol and campesterol were purchased from Merck (Darmstadt, Germany), 2,2-diphenyl-2-picrylhydrazyl (DPPH) was from Sigma-Aldrich, Merck (St. Louis, MO, USA). Deionised water was a PURELAB ${ }^{\circledR}$ Option-Q system from ELGA LabWater (High Wycombe, UK).

\section{Preparation of salad dressings with cocoa butter}

Oil-in-water emulsions of oil-based salad dressing were prepared using a mixer (Cornell Stand Mixer CSM-B210A; Cornell, Petaling Jaya, Malaysia). Approximately $1.5 \mathrm{~g}$ xanthan gum and $3 \mathrm{~g}$ gum Arabic were added into $140 \mathrm{~mL}$ of hot water $\left(80^{\circ} \mathrm{C}\right)$, with slow stirring for at least $3 \mathrm{~min}$. Then, sodium benzoate $(0.3 \mathrm{~g})$, salt $(6.0 \mathrm{~g})$, sugar $(18 \mathrm{~g})$ and egg yolk $(7.5 \mathrm{~g})$ were added. Next, $10 \mathrm{~mL}$ of vinegar were added into the solution to give a pleasant aroma and avoid aeration. Approximately $150 \mathrm{~mL}$ of blended oil was added slowly with slow mixing. Blended oil was prepared by mixing soybean oil and cocoa butter on a hot plate with continuous mixing (9). A preliminary study was conducted using 0 to $100 \%$ of cocoa butter added to salad dressing. However, addition of more than $50 \%$ cocoa butter into the salad dressing resulted in hard, nonsmooth and non-flowing texture of the dressing, thus 11 formulations of salad dressing with less than $50 \%$ cocoa butter were prepared. The rheological properties and emulsion stability of salad dressing containing $30 \%$ cocoa butter showed insignificant ( $p>0.05$ ) characteristics compared to control. However, addition of 5 to $15 \%$ cocoa butter to salad dressing resulted in undesirable liquefied emulsions. Therefore, only the salad dressings with 0 (which served as control) and $30 \%$ cocoa butter were selected for storage study.

\section{Storage conditions for salad dressings}

The salad dressings with 0 and $30 \%$ cocoa butter were prepared and placed in a transparent container similar to the one for commercial salad dressing. All the samples were stored at two temperatures, 4 and $30^{\circ} \mathrm{C}$, for 28 days. This storage period was selected because storage after 28 days resulted in inappropriate texture, colour and appearance of oil on top layer of the dressing, thus making it unsuitable for further use. Storage temperature was chosen based on home and industry practices (10). Changes during storage at the different temperatures were evaluated for 28 days at 7 days intervals. The oil from commercial salad dressing and salad dressings with 0 and $30 \%$ cocoa butter stored at 4 and $30{ }^{\circ} \mathrm{C}$ was separated by centrifugation at $1177 \times g$ (Sorvall ${ }^{\mathrm{TM}}$ Legend ${ }^{\mathrm{TM}}$ Micro 17; Thermo Fisher Scientific, Waltham, MA, USA) for $10 \mathrm{~min}$ before further analysis.

\section{Rheological analysis}

Rheological analysis was done to compare the viscoelastic properties of the salad dressing with cocoa butter during 28 days of storage at 4 and $30^{\circ} \mathrm{C}$ using a dynamic controlled stress rheometer (HAAKE RheoStress RS6000; Thermo Fisher Scientific, Karlsruhe, Germany). A diameter of the parallel-plate geometry of $35 \mathrm{~mm}$ and a gap of $1 \mathrm{~mm}$, measuring device with a temperature unit and a programmable water bath (HAAKE K20; Thermo Fisher Scientific) with a universal temperature controller were used. The rheological measurements (plotted rheograms of shear stress over shear rate) were determined at 0 to $20 \mathrm{~Pa}$, shear rate at $0.5 \mathrm{~min}^{-1}$ and 
temperature was controlled at $20^{\circ} \mathrm{C}$. Power law model (flow consistency index $(K)$, flow index $(n)$ and apparent viscosity (n)) was used to describe the steady shear rheological properties of samples (9). The data were analysed using HAAKE RheoWin 3 software (11).

\section{Emulsion stability test}

Emulsion stability was determined by measuring the mass (g) of oil separated from the salad dressing after centrifugation. The newly formulated salad dressing with cocoa butter and control were incubated at $50{ }^{\circ} \mathrm{C}$ for $24 \mathrm{~h}$. Approximately $1 \mathrm{~g}$ of each sample was placed in the centrifuge tubes and centrifuged for 10 min at $865 \times g$ (Sorvall ${ }^{\mathrm{TM}}$ Legend ${ }^{\mathrm{TM}}$ Micro 17; ThermoFisher Scientific) at room temperature to separate the top oil layer (12).

\section{Oxidative analysis}

Oxidative analysis was done to measure the number of double bonds, oxidation process and amount of fatty acids in the salad dressings. The iodine value measures the number of reactive double bonds present in the salad dressing. A higher iodine value indicates more double bonds present in the salad dressing. It was determined according to AOCS method $\mathrm{Cd}$ $1 \mathrm{~d}-92$ (13). Peroxide value was determined according to AOCS method Cd 8-53 (14), which measures the primary oxidation processes mainly from hydroperoxides present in the emulsion. The acid value (which is twice the free fatty acid value) measures the amount of fatty acids in the sample. The amount of free fatty acids in samples was estimated by determining the volume of alkali that must be added into the dressing to reach a neutral $\mathrm{pH}$ value. Acid value of the salad dressing was determined according to AOCS method Ca 5a-40 (15).

\section{Determination of phytosterols}

About $200 \mathrm{mg}$ of salad dressing were added into $50-\mathrm{mL}$ round-bottomed flask followed by the addition of $250 \mu \mathrm{L}$ of 5-a cholestane $(1000 \mu \mathrm{g} / \mathrm{mL})$ in methanol as internal standard and $2 \mathrm{~mL}$ of $2 \mathrm{M} \mathrm{KOH}$ in methanol. The mixture was heated under reflux at $90^{\circ} \mathrm{C}$ for $1 \mathrm{~h}$. After that, $4 \mathrm{~mL}$ of deionised water and ethyl acetate were added to the mixture. The aqueous phase was washed three times with diethyl ether. Finally, the diethyl ether solution was dried using anhydrous sodium sulfate, filtered and then dried in a nitrogen stream. The amount of phytosterols present in the salad dressing was determined using high-performance liquid chromatography (HPLC) coupled with UV-Vis detector (1200 Series; Agilent Technologies, Santa Clara, CA, USA) and $\mathrm{C}_{8}$ narrow-bore column (150 $\mathrm{mm} \times 2.1 \mathrm{~mm}, 5 \mu \mathrm{m}$; Supelco, Bellefonte, PA, USA) (16). In order to quantify the mass fraction of phytosterols $(\mu \mathrm{g} / \mathrm{g})$ in the salad dressing mass, the following equation was used:

$$
w(\text { phytosterol })=y(\text { phytosterol }) \cdot \frac{V(\text { extract })}{m(\text { sample })}
$$

\section{Determination of antioxidant activity}

\section{DPPH assay}

Samples were extracted using an orbital shaker (Unimax 1010; Heidolph Instruments GmbH \& CO. KG, Schwabach, Germany) at $200 \mathrm{rpm}$ with $70 \%$ aqueous ethanol for $2 \mathrm{~h}$ at $50^{\circ} \mathrm{C}$. The stock solution of the radical, prepared by dissolving 24 $\mathrm{mg}$ DPPH in $100 \mathrm{~mL}$ methanol, was kept in a refrigerator until further use. The working solution of the radical was prepared by diluting the DPPH stock solution with methanol to obtain an absorbance of about 0.98 at $527 \mathrm{~nm}$. Approximately 100 $\mu \mathrm{L}$ of salad dressing extract or standard solution were mixed with $3 \mathrm{~mL}$ DPPH working solution. The mixture was vigorously mixed and left at room temperature in a dark room for 30 min. Absorbance $(A)$ was measured with a spectrophotometer (GENESYS ${ }^{\text {TM }}$ 20; Thermo Fisher Scientific) at $517 \mathrm{~nm}$ using Trolox as a standard (17). Antioxidant activity (\%) was determined as follows:

$$
\text { Antioxidant activity }=\frac{A_{\text {control }}-A_{\text {sample }}}{A_{\text {control }}} \cdot 100
$$

\section{Total phenolic content}

About $200 \mathrm{mg}$ of salad dressing were extracted using an orbital shaker (Unimax 1010; Heidolph Instruments GmbH \& CO. KG) at $200 \mathrm{rpm}$ with $2 \mathrm{~mL}$ of $70 \%$ aqueous ethanol at room temperature for $2 \mathrm{~h}$. The mixture was centrifuged at $1000 \times g$ (Sorvall $^{\mathrm{TM}}$ Legend $^{\mathrm{TM}}$ Micro 17; Thermo Fisher Scientific) for $15 \mathrm{~min}$. Then, $200 \mu \mathrm{L}$ of supernatant were mixed with 1.5 $\mathrm{mL}$ of Folin-Ciocalteu reagent and allowed to stand at room temperature for $5 \mathrm{~min}$. Approximately $1.5 \mathrm{~mL}$ of $0.566 \mathrm{M}$ sodium hydrogen carbonate solution were added. After $90 \mathrm{~min}$, absorbance was read at $725 \mathrm{~nm}$ (GENESYS ${ }^{\text {TM }}$ 20; Thermo Fisher Scientific). A calibration curve was obtained using gallic acid as standard, and from it, total phenolic content was determined and the results were expressed in $\mathrm{mg}$ of gallic acid per $100 \mathrm{~g}$ of oil (18).

\section{Statistical analysis}

A one-way analysis of variance for all data was carried out to determine the significance of the individual differences using Minitab 16 (19). Significant differences $(p<0.05)$ among the mean values were determined by Tukey's test for one-way ANOVA.

\section{RESULTS AND DISCUSSION}

\section{Rheological properties of salad dressings}

The flow consistency index $(K)$ values of commercial salad dressing and dressings with 0 and $30 \%$ cocoa butter were analysed from 0 to 28 days at 4 and $30^{\circ} \mathrm{C}$. The viscosity of all salad dressings increased during 28 days of storage (Table 1 ). The flow consistency index value of salad dressing with 30 
Table 1. Flow consistency index $(K)$, flow behaviour index $(n)$ and apparent viscosity $(\eta)$ of commercial salad dressing and salad dressings with 0 and $30 \%$ cocoa butter during storage at 4 and $30^{\circ} \mathrm{C}$

\begin{tabular}{|c|c|c|c|c|c|c|c|}
\hline \multirow{3}{*}{$\begin{array}{l}\text { Type of salad } \\
\text { dressing }\end{array}$} & \multirow{3}{*}{$\frac{t(\text { storage })}{\text { day }}$} & \multicolumn{6}{|c|}{ Temperature $/{ }^{\circ} \mathrm{C}$} \\
\hline & & 4 & 30 & 4 & 30 & 4 & 30 \\
\hline & & \multicolumn{2}{|c|}{$K /\left(\mathrm{Pa} \cdot \mathrm{s}^{\mathrm{n}}\right)$} & \multicolumn{2}{|c|}{$n$} & \multicolumn{2}{|c|}{$\eta /(\mathrm{Pa} \cdot \mathrm{s})$} \\
\hline \multirow{5}{*}{ Commercial } & 0 & $(19.71 \pm 0.06)^{\mathrm{Da}}$ & $(19.4 \pm 0.2)^{\mathrm{Da}}$ & $(0.45 \pm 0.01)^{\mathrm{Aa}}$ & $(0.45 \pm 0.03)^{\mathrm{Aa}}$ & $(2.7 \pm 1.0)^{\mathrm{Ea}}$ & $(2.6 \pm 0.4)^{\mathrm{Ea}}$ \\
\hline & 7 & $(22.90 \pm 0.05)^{\mathrm{Ca}}$ & $(20.40 \pm 0.05)^{\mathrm{cc}}$ & $(0.43 \pm 0.01)^{\mathrm{Bb}}$ & $(0.44 \pm 0.04)^{\mathrm{Aa}}$ & $(2.9 \pm 0.2)^{\mathrm{Da}}$ & $(2.7 \pm 1.0)^{\mathrm{DC}}$ \\
\hline & 14 & $(24.70 \pm 0.06)^{\mathrm{Ba}}$ & $(21.4 \pm 0.2)^{\mathrm{BC}}$ & $(0.42 \pm 0.06)^{\mathrm{Cb}}$ & $(0.43 \pm 0.04)^{\mathrm{Ba}}$ & $(3.1 \pm 0.6)^{\mathrm{Ca}}$ & $(2.8 \pm 0.5)^{\mathrm{Cc}}$ \\
\hline & 21 & $(27.67 \pm 0.01)^{\mathrm{Aa}}$ & $(25.3 \pm 0.1)^{A C}$ & $(0.40 \pm 0.04)^{\mathrm{Db}}$ & $(0.4 \pm 0.1)^{\mathrm{Ca}}$ & $(3.3 \pm 0.9)^{\mathrm{Ba}}$ & $(2.9 \pm 0.1)^{\mathrm{BC}}$ \\
\hline & 28 & $(27.38 \pm 0.07)^{\mathrm{Aa}}$ & $(25.51 \pm 0.07)^{\mathrm{Ac}}$ & $(0.4 \pm 0.1)^{\mathrm{Eb}}$ & $(0.41 \pm 0.03)^{\mathrm{Da}}$ & $(3.4 \pm 0.1)^{\mathrm{Aa}}$ & $(3.2 \pm 0.1)^{\mathrm{Ab}}$ \\
\hline \multirow{5}{*}{$\begin{array}{l}0 \% \text { cocoa butter } \\
\text { (control) }\end{array}$} & 0 & $(19.60 \pm 0.09)^{\mathrm{Da}}$ & $(19.2 \pm 0.3)^{\mathrm{Da}}$ & $(0.45 \pm 0.03)^{\mathrm{Aa}}$ & $(0.4 \pm 0.3)^{\mathrm{Aa}}$ & $(2.69 \pm 1.01)^{\mathrm{Ea}}$ & $(2.6 \pm 0.9)^{\mathrm{Ea}}$ \\
\hline & 7 & $(22.53 \pm 0.08)^{\mathrm{Ca}}$ & $(20.93 \pm 0.07)^{\mathrm{Cc}}$ & $(0.43 \pm 0.06)^{\mathrm{BC}}$ & $(0.45 \pm 0.01)^{\mathrm{Ba}}$ & $(3.0 \pm 0.7)^{\mathrm{Da}}$ & $(2.6 \pm 1.0)^{\mathrm{Dc}}$ \\
\hline & 14 & $(25.82 \pm 0.06)^{\mathrm{Ba}}$ & $(22.9 \pm 0.2)^{\mathrm{BC}}$ & $(0.42 \pm 0.04)^{\mathrm{BC}}$ & $(0.44 \pm 0.04)^{\mathrm{Ca}}$ & $(3.1 \pm 0.3)^{\mathrm{Ca}}$ & $(2.8 \pm 0.4)^{\mathrm{Cc}}$ \\
\hline & 21 & $(29.49 \pm 0.02)^{\mathrm{Aa}}$ & $(25.0 \pm 0.4)^{A c}$ & $(0.41 \pm 0.02)^{\mathrm{Cc}}$ & $(0.43 \pm 0.03)^{\mathrm{Da}}$ & $(3.3 \pm 0.9)^{\mathrm{Ba}}$ & $(3.0 \pm 0.1)^{B C}$ \\
\hline & 28 & $(30.7 \pm 0.4)^{\mathrm{Aa}}$ & $(24.7 \pm 0.3)^{\mathrm{Ac}}$ & $(0.40 \pm 0.02)^{\mathrm{Dc}}$ & $(0.42 \pm 0.03)^{\mathrm{Ea}}$ & $(3.4 \pm 0.4)^{\mathrm{Aa}}$ & $(3.1 \pm 0.7)^{A C}$ \\
\hline \multirow{5}{*}{$30 \%$ cocoa butter } & 0 & $(21.5 \pm 0.1)^{\mathrm{Da}}$ & $(21.46 \pm 0.06)^{\mathrm{Da}}$ & $(0.46 \pm 0.01)^{\mathrm{Aa}}$ & $(0.46 \pm 0.08)^{\mathrm{Aa}}$ & $(2.7 \pm 1.0)^{\mathrm{Ea}}$ & $(2.6 \pm 0.3)^{\mathrm{Ea}}$ \\
\hline & 7 & $(26.67 \pm 0.06)^{\mathrm{Ca}}$ & $(23.5 \pm 0.2)^{\mathrm{cc}}$ & $(0.43 \pm 0.02)^{\mathrm{Bb}}$ & $(0.45 \pm 0.01)^{\mathrm{Ba}}$ & $(2.9 \pm 0.5)^{\mathrm{Da}}$ & $(2.7 \pm 0.5)^{\mathrm{Dc}}$ \\
\hline & 14 & $(27.5 \pm 0.3)^{\mathrm{Ba}}$ & $(25.5 \pm 0.1)^{\mathrm{BC}}$ & $(0.42 \pm 0.03)^{\mathrm{Cb}}$ & $(0.43 \pm 0.02)^{\mathrm{Ca}}$ & $(3.2 \pm 0.4)^{\mathrm{Ca}}$ & $(2.9 \pm 1.0)^{\complement c}$ \\
\hline & 21 & $(29.2 \pm 0.1)^{\mathrm{Aa}}$ & $(27.3 \pm 0.3)^{\mathrm{Ac}}$ & $(0.40 \pm 0.02)^{\mathrm{Db}}$ & $(0.41 \pm 0.03)^{\mathrm{Da}}$ & $(3.3 \pm 0.6)^{\mathrm{Ba}}$ & $(3.1 \pm 0.5)^{\mathrm{BC}}$ \\
\hline & 28 & $(29.87 \pm 0.06)^{\mathrm{Aa}}$ & $(26.28 \pm 0.03)^{A C}$ & $(0.39 \pm 0.02)^{\mathrm{Eb}}$ & $(0.40 \pm 0.02)^{\mathrm{Ea}}$ & $(3.5 \pm 0.3)^{\mathrm{Aa}}$ & $(3.1 \pm 0.8)^{\mathrm{AC}}$ \\
\hline
\end{tabular}

Mean values in the same column with different capital letters are significantly different $(p<0.05)$ between storage durations. Mean values in the same row with different lower-case letters are significantly different $(p<0.05)$ between different temperatures. Results are expressed as mean value \pm standard deviation $(N=3)$

$\%$ cocoa butter (21.5 to $\left.29.87 \mathrm{~Pa} \cdot \mathrm{s}^{\mathrm{n}}\right)$ stored at $4{ }^{\circ} \mathrm{C}$ was higher than of the dressing with $0 \%$ cocoa butter $\left(19.60\right.$ to $\left.30.7 \mathrm{~Pa} \cdot \mathrm{s}^{\mathrm{n}}\right)$ and commercial salad dressing (19.71 to $27.38 \mathrm{~Pa} \cdot \mathrm{s}^{\mathrm{n}}$ ). A higher value of $K$ represents a more viscous consistency of emulsions (20), suggesting that the addition of cocoa butter enhanced the viscous properties of the salad dressing and acted as thickener. The high viscosity of the salad dressing might be due to a strong intermolecular force of the molecules within the liquid. It is suspected that with longer storage, the structure of salad dressing became more stable due to its acidification, thus supporting protein network, but too long storage period resulted in dressing with hard texture. Higher values of flow consistency index were found at $4{ }^{\circ} \mathrm{C}$ than at $30^{\circ} \mathrm{C}$ (Table 1). Dimitreli and Thomareis (21) stated that the flow consistency index decreased with the increase in temperature, which indicated that at high temperatures the apparent viscosity value was reduced. As the temperature increases, the degree of molecular motion also increases, thus reducing the short-range attractive forces between molecules and lowering the viscosity of the liquid (22).

The flow behaviour index $(n)$ indicates the degree of pseudoplasticity. The greater the shear-thinning of the product, the closer the $n$ value to zero. All the $n$ values for the control and the treated salad dressing were lower than 1, ranging from 0.39 to 0.46 (Table 1). A significant difference in $n$ values was observed among samples during storage, indicating that they had quite stable gel-like structures. At the beginning of storage, the $n$ value was significantly $(p<0.05)$ high of most samples and then it decreased up to 28 days of storage. Addition of $30 \%$ cocoa butter led to a more pronounced pseudoplastic behaviour of the dressing. At the beginning of storage at $4{ }^{\circ} \mathrm{C}$, salad dressing with $30 \%$ cocoa butter exhibited significantly higher $(p<0.05)$ flow behaviour index $(0.46)$ than the commercial salad dressing and the dressing with $0 \%$ cocoa butter (0.45), which indicates more elastic or gel-like structure of the dressing as a result of the incorporation of another emulsifier and mixing soybean oil with cocoa butter instead of the use of soybean oil alone. Overall, the flow behaviour index of all samples increased with the increase in temperature, except at the beginning of storage (Table 1).

The apparent viscosity $(\eta)$ test showed there was a significant increase $(p<0.05)$ in viscosity during 28 days of storage in commercial salad dressing sample (Table 1). Bienvenue et al. (23) also observed that the apparent viscosity of concentrated skimmed milk increases significantly after storage for $6 \mathrm{~h}$ at $50{ }^{\circ} \mathrm{C}$. The apparent viscosity of all types of salad dressing used in this study decreased as the temperature increased, which might be because the change in temperature affects their physical characteristics. Similarly, Ahmed (24) found that the apparent viscosity and flow consistency index of ginger paste decreased significantly $(p<0.05)$ with an increase in temperature.

\section{Analysis of emulsion stability}

Emulsion stability of commercial salad dressing (Table 2) was the highest ( 92.6 to $87.09 \%$ ), followed by the dressing with $30 \%$ cocoa butter (88.2 to $82.6 \%$ ) and $0 \%$ cocoa butter ( 87.5 to 81.8 $\%)$. Leroux et al. (25) stated that pectin could be used to produce stable emulsions in the same manner as gum Arabic. Therefore, addition of gum Arabic to commercial salad dressing and dressings with 0 and $30 \%$ cocoa butter stabilised the emulsion. Emulsion destabilisation mechanism was proposed to be dependent on several factors such as pressure difference between dispersed and continuous phase, droplet size, and viscosity of the continuous phase (26). In addition, it is important to highlight that the 
Table 2. Emulsion stability in different salad dressings during storage at 4 and $30^{\circ} \mathrm{C}$

\begin{tabular}{lccc} 
& & \multicolumn{2}{c}{ Temperature/ ${ }^{\circ} \mathrm{C}$} \\
\cline { 3 - 4 } Type of salad & t(storage)/day & 4 & 30 \\
\cline { 3 - 4 } dressing & 0 & $(92.6 \pm 0.3)^{\mathrm{Aa}}$ & $(92.3 \pm 0.3)^{\mathrm{Aa}}$ \\
& 7 & $(92.1 \pm 0.4)^{\mathrm{Ba}}$ & $(90.1 \pm 0.4)^{\mathrm{Bc}}$ \\
Commercial & 14 & $(91.8 \pm 0.2)^{\mathrm{Ca}}$ & $(89.9 \pm 0.2)^{\mathrm{Cc}}$ \\
& 21 & $(91.3 \pm 0.8)^{\mathrm{Da}}$ & $(88.4 \pm 0.6)^{\mathrm{Dc}}$ \\
& 28 & $(91.2 \pm 0.2)^{\mathrm{Ea}}$ & $(87.09 \pm 0.08)^{\mathrm{cc}}$ \\
& 0 & $(87.5 \pm 0.4)^{\mathrm{Aa}}$ & $(85.98 \pm 0.05)^{\mathrm{Ac}}$ \\
0 \% cocoa & 7 & $(85.57 \pm 0.06)^{\mathrm{Aa}}$ & $(83.3 \pm 0.1)^{\mathrm{Bc}}$ \\
butter (control) & 14 & $(85.29 \pm 0.05)^{\mathrm{Ca}}$ & $(83.99 \pm 0.05)^{\mathrm{Cc}}$ \\
& 21 & $(84.9 \pm 0.4)^{\mathrm{Da}}$ & $(82.8 \pm 0.6)^{\mathrm{Dc}}$ \\
& 28 & $(83.1 \pm 0.8)^{\mathrm{Ea}}$ & $(81.8 \pm 0.2)^{\mathrm{Ec}}$ \\
& 0 & $(88.2 \pm 0.4)^{\mathrm{Ab}}$ & $(87.9 \pm 0.1)^{\mathrm{Aa}}$ \\
$30 \%$ cocoa & 7 & $(87.6 \pm 0.1)^{\mathrm{Ba}}$ & $(85.1 \pm 0.3)^{\mathrm{Bc}}$ \\
butter & 14 & $(86.9 \pm 0.1)^{\mathrm{Ca}}$ & $(84.2 \pm 0.1)^{\mathrm{Cc}}$ \\
& 21 & $(85.25 \pm 0.02)^{\mathrm{Da}}$ & $(83.58 \pm 0.02)^{\mathrm{Dc}}$ \\
& 28 & $(84.9 \pm 0.4)^{\mathrm{Ea}}$ & $(82.6 \pm 0.1)^{\mathrm{Ec}}$ \\
\hline
\end{tabular}

Mean values in the same column with different capital letters are significantly different $(p<0.05)$ between storage durations. Mean values in the same row with different lower-case letters are significantly different $(\mathrm{p}<0.05)$ between different temperatures. Results are expressed as mean value \pm standard deviation $(N=3)$

stability of salad dressing with $30 \%$ cocoa butter was greater than of that with $0 \%$ cocoa butter. Table 2 shows that higher emulsion stability of all samples was obtained at 4 than at $30^{\circ} \mathrm{C}$ on the 7th day of storage. Similar to this study, Abu Ghoush et al. (27) found that the emulsion stability of mayonnaise significantly decreased during storage with the increase of temperature from 4 to 23 and $40^{\circ} \mathrm{C}$. This could be due to the rapid flocculation and/ or coalescence of small droplets which occurs at increased storage temperatures (27).

\section{Oxidative stability of salad dressings}

Salad dressings had lower iodine value ( 30.5 to $42.5 \mathrm{~g} / 100 \mathrm{~g}$ ) at 30 than at $4{ }^{\circ} \mathrm{C}$ (31.9 to $\left.42.9 \mathrm{~g} / 100 \mathrm{~g}\right)$. Liauw et al. (28) stated that high temperature reduced the iodine value because it initiates the breakdown of carbon chain bonding, thus forming saturated carbon chain. Nevertheless, the iodine value of commercial salad dressing and dressings with 0 and $30 \%$ cocoa butter stored at 4 and $30{ }^{\circ} \mathrm{C}$ was significantly $(p<0.05)$ reduced during 28 days of storage (Table 3 ). The decrease in the iodine value is consistent with the oxidation of the oil blends. The observation of the droplet size and distribution in the salad dressing suggested that the network build-up by oil droplets, protein aggregates and gums was influenced by chilling and extended duration of storage (29). The salad dressing with 30 $\%$ cocoa butter had high iodine value, but its oxidative stability was relatively low. This might be due to the blend of cocoa butter and soybean oil in the salad dressing resulting in high double bond content.

Peroxide value of commercial salad dressing increased from 2.5 to $5.6 \mathrm{mmol} / \mathrm{kg}$ during storage for 28 days at 4 and $30{ }^{\circ} \mathrm{C}$, while of the dressing with $0 \%$ cocoa butter it increased from 1.32 to $5.3 \mathrm{mmol} / \mathrm{kg}$ and of that with $30 \%$ cocoa butter from 1.3 to $5.3 \mathrm{mmol} / \mathrm{kg}$ (Table 3). Siddique et al. (30) reported that the vulnerability of oil to light and air at room temperature increased the peroxide value. In this study, commercial and salad dressing with $0 \%$ cocoa butter have higher content of unsaturated fatty acids (originating from soybean oil) than the dressing with $30 \%$ cocoa butter at the beginning of storage. High peroxide value of commercial and salad dressing with $0 \%$ cocoa butter might be due to their oxidation during preparation. According to Ramezani (31), the peroxide value of sunflower oil stored in a clear PET packaging during 365 days increased from $4 \mathrm{mmol} / \mathrm{kg}$ at $26.9^{\circ} \mathrm{C}$ to $8 \mathrm{mmol} / \mathrm{kg}$ at $38^{\circ} \mathrm{C}$. In a study by

Table 3. lodine, peroxide and acid values in different salad dressings during storage at 4 and $30^{\circ} \mathrm{C}$

\begin{tabular}{|c|c|c|c|c|c|c|c|}
\hline \multirow{3}{*}{$\begin{array}{l}\text { Type of salad } \\
\text { dressing }\end{array}$} & \multirow{3}{*}{$\frac{t \text { (storage) }}{\text { day }}$} & \multicolumn{6}{|c|}{ Temperature $/{ }^{\circ} \mathrm{C}$} \\
\hline & & 4 & 30 & 4 & 30 & 4 & 30 \\
\hline & & \multicolumn{2}{|c|}{ lodine value/(g/100 g) } & \multicolumn{2}{|c|}{ Peroxide value $/(\mathrm{mmol} / \mathrm{kg})$} & \multicolumn{2}{|c|}{ Acid value/(mg/g) } \\
\hline \multirow{5}{*}{ Commercial } & 0 & $(42.3 \pm 0.2)^{\mathrm{Aa}}$ & $(42.1 \pm 0.1)^{\mathrm{Aa}}$ & $(2.5 \pm 0.2)^{\mathrm{Da}}$ & $(2.6 \pm 0.2)^{\mathrm{Da}}$ & $(1.44 \pm 0.05)^{\mathrm{Ca}}$ & $(1.47 \pm 0.01)^{\mathrm{ca}}$ \\
\hline & 7 & $(39.9 \pm 0.3)^{\mathrm{Ba}}$ & $(36.6 \pm 0.8)^{B C}$ & $(3.1 \pm 0.3)^{\mathrm{cb}}$ & $(4.1 \pm 0.2)^{\mathrm{Ca}}$ & $(1.50 \pm 0.02)^{\mathrm{Bb}}$ & $(1.62 \pm 0.02)^{\mathrm{Ba}}$ \\
\hline & 14 & $(36.4 \pm 0.2)^{\mathrm{Ca}}$ & $(35.1 \pm 0.5)^{\mathrm{Cc}}$ & $(3.4 \pm 0.2)^{\mathrm{cb}}$ & $(4.1 \pm 0.2)^{\mathrm{Ca}}$ & $(1.53 \pm 0.03)^{\mathrm{Ab}}$ & $(1.63 \pm 0.02)^{\mathrm{Ba}}$ \\
\hline & 21 & $(34.5 \pm 0.2)^{\mathrm{Da}}$ & $(32.7 \pm 0.2)^{D C}$ & $(4.1 \pm 0.4)^{\mathrm{Bb}}$ & $(5.0 \pm 0.5)^{\mathrm{Ba}}$ & $(1.58 \pm 0.02)^{\mathrm{Ab}}$ & $(1.66 \pm 0.02)^{\mathrm{Aa}}$ \\
\hline & 28 & $(31.9 \pm 1.0)^{\mathrm{Ea}}$ & $(31.3 \pm 0.2)^{\mathrm{Ec}}$ & $(4.2 \pm 0.1)^{\mathrm{Ab}}$ & $(5.6 \pm 0.5)^{\mathrm{Aa}}$ & $(1.64 \pm 0.02)^{\mathrm{Aa}}$ & $(1.68 \pm 0.02)^{\mathrm{Aa}}$ \\
\hline \multirow{5}{*}{$\begin{array}{l}0 \% \text { cocoa butter } \\
\text { (control) }\end{array}$} & 0 & $(42.8 \pm 0.5)^{\mathrm{Aa}}$ & $(42.5 \pm 0.3)^{\mathrm{Aa}}$ & $(1.32 \pm 0.09)^{\mathrm{Da}}$ & $(1.8 \pm 0.2)^{\mathrm{Ca}}$ & $(1.55 \pm 0.04)^{\mathrm{Ca}}$ & $(1.56 \pm 0.03)^{\mathrm{ca}}$ \\
\hline & 7 & $(41.0 \pm 0.7)^{\mathrm{Ba}}$ & $(35.5 \pm 0.4)^{B C}$ & $(2.3 \pm 0.2)^{\mathrm{cb}}$ & $(3.59 \pm 0.08)^{\mathrm{Ca}}$ & $(1.59 \pm 0.02)^{\mathrm{Bb}}$ & $(1.65 \pm 0.01)^{\mathrm{Ba}}$ \\
\hline & 14 & $(36.7 \pm 0.4)^{\mathrm{Ca}}$ & $(33.1 \pm 0.5)^{\mathrm{cc}}$ & $(3.6 \pm 0.1)^{\mathrm{Cb}}$ & $(4.18 \pm 0.09)^{\mathrm{Ba}}$ & $(1.61 \pm 0.02)^{\mathrm{Ab}}$ & $(1.64 \pm 0.01)^{\mathrm{Ba}}$ \\
\hline & 21 & $(35.7 \pm 0.7)^{\mathrm{Da}}$ & $(32.0 \pm 0.5)^{\mathrm{DC}}$ & $(4.0 \pm 0.3)^{\mathrm{Bb}}$ & $(5.0 \pm 0.3)^{\mathrm{Aa}}$ & $(1.66 \pm 0.02)^{\mathrm{Ab}}$ & $(1.72 \pm 0.03)^{\mathrm{Aa}}$ \\
\hline & 28 & $(33.7 \pm 0.7)^{\mathrm{Ea}}$ & $(30.6 \pm 0.7)^{\mathrm{EC}}$ & $(4.63 \pm 0.05)^{\mathrm{Ab}}$ & $(5.3 \pm 0.2)^{\mathrm{Aa}}$ & $(1.74 \pm 0.02)^{\mathrm{Ab}}$ & $(1.79 \pm 0.01)^{\mathrm{Aa}}$ \\
\hline \multirow{5}{*}{$30 \%$ cocoa butter } & 0 & $(42.9 \pm 0.8)^{\mathrm{Aa}}$ & $(42.3 \pm 0.2)^{\mathrm{Aa}}$ & $(1.3 \pm 0.6)^{\mathrm{Da}}$ & $(1.7 \pm 0.2)^{\mathrm{Da}}$ & $(1.46 \pm 0.03)^{\mathrm{Ca}}$ & $(1.48 \pm 0.02)^{\mathrm{Ca}}$ \\
\hline & 7 & $(41.4 \pm 0.5)^{\mathrm{Ba}}$ & $(36.2 \pm 0.7)^{B C}$ & $(2.0 \pm 0.2)^{\mathrm{cb}}$ & $(3.1 \pm 0.2)^{\mathrm{Ca}}$ & $(1.49 \pm 0.03)^{\mathrm{Bb}}$ & $(1.59 \pm 0.01)^{\mathrm{Ba}}$ \\
\hline & 14 & $(40.5 \pm 0.7)^{\mathrm{Ca}}$ & $(33.6 \pm 0.6)^{\mathrm{cc}}$ & $(2.5 \pm 0.2)^{\mathrm{cb}}$ & $(3.4 \pm 0.2)^{\mathrm{Ca}}$ & $(1.51 \pm 0.01)^{\mathrm{Ab}}$ & $(1.61 \pm 0.03)^{\mathrm{Aa}}$ \\
\hline & 21 & $(38.7 \pm 0.2)^{\mathrm{Da}}$ & $(32.2 \pm 0.6)^{D C}$ & $(3.7 \pm 0.2)^{\mathrm{Bb}}$ & $(4.0 \pm 0.1)^{\mathrm{Ba}}$ & $(1.54 \pm 0.03)^{\mathrm{Ab}}$ & $(1.63 \pm 0.01)^{\mathrm{Aa}}$ \\
\hline & 28 & $(35.6 \pm 0.3)^{\mathrm{Ea}}$ & $(30.5 \pm 0.4)^{\mathrm{Ec}}$ & $(4.7 \pm 0.2)^{\mathrm{Ab}}$ & $(5.3 \pm 0.1)^{\mathrm{Aa}}$ & $(1.61 \pm 0.02)^{\mathrm{Ab}}$ & $(1.70 \pm 0.04)^{\mathrm{Aa}}$ \\
\hline
\end{tabular}

Mean values in the same column with different capital letters are significantly different $(p<0.05)$ between storage durations. Mean values in the same row with different lower-case letters are significantly different $(p<0.05)$ between different temperatures. Results are expressed as mean value \pm standard deviation $(N=3)$ 
Sengar et al. (32) hydrogenated palm kernel oil blended with butter in ratio 3:1 and 3:2 with different physicochemical parameters and free fatty acid content was found to easily oxidize at room temperature after ten months of storage in comparison with refrigerated storage. The refrigerating condition was efficiently proven to control oxidation in control samples up to the sixth month of storage in any of the packaging materials. In this study, salad dressing with $30 \%$ cocoa butter had the lowest peroxide value, which indicates that the addition of cocoa butter reduced the salad dressing oxidation.

Table 3 shows that longer duration of storage resulted in higher acid value. On the final day of storage at $4{ }^{\circ} \mathrm{C}$, the salad dressing with $30 \%$ cocoa butter had lower acid value than commercial and salad dressing with $0 \%$ cocoa butter. It seems that the presence of unsaturated fatty acids (linoleic and oleic acids) in soybean oil increased the acid value of commercial and salad dressing with $0 \%$ cocoa butter. Canakci (33) stated that deterioration of the oil occurred easily due to the oxidation of the unsaturated fatty acids. The acid value of biodiesel samples also increased with increasing storage time as a result of hydrolysis of fatty acid methyl esters to fatty acids. This might be due to the storage conditions with a large air surface contact of biodiesel or due to the fatty acid composition of the vegetable oils used as raw materials (34). The acid values were higher at $30^{\circ} \mathrm{C}$ than at $4{ }^{\circ} \mathrm{C}$ (Table 3 ). Similar results were obtained by Liauw et al. (28). They studied the effect of extraction temperature from 30 to $55^{\circ} \mathrm{C}$ of neem oil using $n$-hexane and ethanol on its acid value. The high temperature during the extraction process may increase the acid value since the temperature influences the hydrolysis of the sample (35).

Żyżelewicz et al. (36) concluded that cocoa butter has high oxidative stability due to its chemical composition, i.e. high content of saturated fatty acids and natural antioxidants (tocopherols and tocotrienols). The salad dressing with $30 \%$ cocoa butter had the highest iodine value, and the lowest peroxide and acid values compared to commercial and salad dressing with $0 \%$ cocoa butter, which suggests that this salad dressing can be stored at low temperature for a long period with low deterioration.

\section{Phytosterol content in salad dressings}

The phytosterol content in cocoa butter and soybean oil was determined before their addition to the formulated salad dressing (data not shown). Soybean oil had the highest mass fraction of campesterol $(2028 \mu \mathrm{g} / \mathrm{g})$, followed by $\beta$-sitosterol $(1537 \mu \mathrm{g} / \mathrm{g})$ and stigmasterol $(1423 \mu \mathrm{g} / \mathrm{g})$, while cocoa butter had the highest amount of $\beta$-sitosterol $(2294 \mu \mathrm{g} / \mathrm{g})$, then campesterol $(2029 \mu \mathrm{g} / \mathrm{g})$ and stigmasterol $(1665 \mu \mathrm{g} / \mathrm{g})$. Cocoa butter had a higher total content of phytosterols $(5988 \mu \mathrm{g} / \mathrm{g})$ than soybean oil $(4990 \mu \mathrm{g} / \mathrm{g})$. The content of phytosterols in the salad dressing during storage is shown in Table 4. Total phytosterol content in commercial salad dressing was significantly $(p<0.05)$ higher at the beginning of storage at 4 and $30^{\circ} \mathrm{C}$ than after 28 days of storage, and a similar decreasing pattern in total phytosterol content was observed in salad dressings with 0 and $30 \%$ cocoa butter.

The increased storage temperature decreased the phytosterol content in all salad dressing samples. Osada et al. (37) studied the loss of phytosterols or sterol oxide during heating of cholesterol at $100^{\circ} \mathrm{C}$ for $24 \mathrm{~h}$. Nourooz-Zadeh and Appelqvist (38) found that the total amount of phytosterols decreased with prolonged storage. They indicated that phytosterol oxidation products occurred with the loss of phytosterols in wheat flour from 2 to 36 months storage, increasing from 35 to $328 \mu \mathrm{g} / \mathrm{g}$. Food enriched with phytosterol that has been exposed to light, heat, air, water and metal ions (oxidation-promoting factors) has a high amount of sterol oxidation products due to the free

Table 4. Phytosterol content in different salad dressings during storage at 4 and $30^{\circ} \mathrm{C}$

\begin{tabular}{|c|c|c|c|c|c|c|c|c|c|}
\hline \multirow{4}{*}{$\begin{array}{l}\text { Type of } \\
\text { salad } \\
\text { dressing }\end{array}$} & \multirow{4}{*}{$\frac{t \text { (storage) }}{\text { day }}$} & \multicolumn{8}{|c|}{ Temperature $/{ }^{\circ} \mathrm{C}$} \\
\hline & & 4 & 30 & 4 & 30 & 4 & 30 & 4 & 30 \\
\hline & & \multicolumn{8}{|c|}{$w($ phytosterol $) /(\mu \mathrm{g} / \mathrm{g})$} \\
\hline & & \multicolumn{2}{|c|}{ Campesterol } & \multicolumn{2}{|c|}{ Stigmasterol } & \multicolumn{2}{|c|}{$\beta$-sitosterol } & \multicolumn{2}{|c|}{ Total phytosterols } \\
\hline \multirow{5}{*}{ Commercial } & 0 & $(1658 \pm 0.06)^{\mathrm{Aa}}$ & $(1680 \pm 0.05)^{\mathrm{Aa}}$ & $(1530 \pm 0.02)^{\mathrm{Aa}}$ & $(1516 \pm 0.03)^{\mathrm{Aa}}$ & $(1845 \pm 0.07)^{\mathrm{Aa}}$ & $(1839 \pm 0.04)^{\mathrm{Aa}}$ & $(5033 \pm 0.09)^{\mathrm{Aa}}$ & $(5005 \pm 0.05)^{A C}$ \\
\hline & 7 & $(1674 \pm 0.07)^{\mathrm{Aa}}$ & $(1641 \pm 0.03)^{\mathrm{Ab}}$ & $(1491 \pm 0.08)^{\mathrm{Ba}}$ & $(1459 \pm 0.01)^{\mathrm{Ba}}$ & $(1804 \pm 0.07)^{\mathrm{Ba}}$ & $(1792 \pm 0.07)^{\mathrm{Ba}}$ & $(4969 \pm 0.01)^{\mathrm{Ba}}$ & $(4892 \pm 0.09)^{\mathrm{BC}}$ \\
\hline & 14 & $(1639 \pm 0.02)^{\mathrm{Aa}}$ & $(1626 \pm 0.02)^{\mathrm{Bb}}$ & $(1447 \pm 0.06)^{\mathrm{Ba}}$ & $(1426 \pm 0.03)^{\mathrm{cb}}$ & $(1787 \pm 0.07)^{\text {Bсa }}$ & $(1766 \pm 0.05)^{\mathrm{Ca}}$ & $(4873 \pm 0.01)^{\mathrm{Ca}}$ & $(4818 \pm 0.04)^{\mathrm{cb}}$ \\
\hline & 21 & $(1604 \pm 0.02)^{\mathrm{Aa}}$ & $(1593 \pm 0.07)^{\mathrm{cb}}$ & $(1335 \pm 0.04)^{\mathrm{Ca}}$ & $(1299 \pm 0.10)^{\mathrm{Db}}$ & $(1767 \pm 0.08)^{\mathrm{Ca}}$ & $(1758 \pm 0.02)^{\mathrm{Ca}}$ & $(4706 \pm 0.02)^{\mathrm{Da}}$ & $(4650 \pm 0.09)^{\mathrm{Db}}$ \\
\hline & 28 & $(1589 \pm 0.02)^{\mathrm{Aa}}$ & $(1568 \pm 0.01)^{\mathrm{Db}}$ & $(1317 \pm 0.06)^{\mathrm{Ca}}$ & $(1292 \pm 0.03)^{\mathrm{Db}}$ & $(1658 \pm 0.01)^{\mathrm{Da}}$ & $(1626 \pm 0.06)^{\mathrm{Db}}$ & $(4564 \pm 0.08)^{\mathrm{Ea}}$ & $(4486 \pm 0.10)^{E c}$ \\
\hline \multirow{5}{*}{$\begin{array}{l}0 \% \text { cocoa } \\
\text { butter } \\
\text { (control) }\end{array}$} & 0 & $(1636 \pm 0.04)^{\mathrm{Aa}}$ & $(1631 \pm 0.05)^{\mathrm{Aa}}$ & $(1517 \pm 0.01)^{\mathrm{Aa}}$ & $(1502 \pm 0.02)^{\mathrm{Aa}}$ & $(1814 \pm 0.03)^{\mathrm{Aa}}$ & $(1806 \pm 0.02)^{\mathrm{Aa}}$ & $(4967 \pm 0.06)^{\mathrm{Aa}}$ & $(4939 \pm 0.08)^{A C}$ \\
\hline & 7 & $(1626 \pm 0.06)^{\mathrm{Ba}}$ & $(1606 \pm 0.05)^{\mathrm{Bb}}$ & $(1414 \pm 0.01)^{\mathrm{Ba}}$ & $(1401 \pm 0.01)^{\mathrm{BC}}$ & $(1775 \pm 0.02)^{\mathrm{Ba}}$ & $(1767 \pm 0.02)^{\mathrm{Ba}}$ & $(4815 \pm 0.01)^{\mathrm{Ba}}$ & $(4774 \pm 0.07)^{\mathrm{Bb}}$ \\
\hline & 14 & $(1621 \pm 0.09)^{\mathrm{Ba}}$ & $(1592 \pm 0.01)^{\mathrm{cb}}$ & $(1402 \pm 0.02)^{\mathrm{Ba}}$ & $(1348 \pm 0.04)^{\mathrm{ca}}$ & $(1765 \pm 0.04)^{\mathrm{Ba}}$ & $(1737 \pm 0.06)^{\mathrm{cb}}$ & $(4788 \pm 0.01)^{\mathrm{Ba}}$ & $(4677 \pm 0.02)^{\mathrm{Cc}}$ \\
\hline & 21 & $(1606 \pm 0.03)^{\mathrm{BCa}}$ & $(1570 \pm 0.03)^{\mathrm{Dc}}$ & $(1370 \pm 0.01)^{\mathrm{BCa}}$ & $(1324 \pm 0.02)^{\mathrm{Db}}$ & $(1735 \pm 0.01)^{\mathrm{BCa}}$ & $(1714 \pm 0.05)^{\mathrm{Da}}$ & $(4711 \pm 0.08)^{\mathrm{Ca}}$ & $(4608 \pm 0.06)^{D C}$ \\
\hline & 28 & $(1588 \pm 0.01)^{\mathrm{Ca}}$ & $(1555 \pm 0.01)^{\mathrm{Ec}}$ & $(1342 \pm 0.01)^{\mathrm{Ca}}$ & $(1315 \pm 0.03)^{\mathrm{Db}}$ & $(1706 \pm 0.03)^{\mathrm{Ca}}$ & $(1691 \pm 0.01)^{\mathrm{Eb}}$ & $(4636 \pm 0.05)^{\mathrm{Da}}$ & $(4561 \pm 0.04)^{\mathrm{EC}}$ \\
\hline \multirow{5}{*}{$\begin{array}{l}30 \% \text { cocoa } \\
\text { butter }\end{array}$} & 0 & $(1815 \pm 0.04)^{\mathrm{Aa}}$ & $(1809 \pm 0.05)^{\mathrm{Aa}}$ & $(1507 \pm 0.01)^{\mathrm{Aa}}$ & $(1495 \pm 0.09)^{\mathrm{Aa}}$ & $(1837 \pm 0.02)^{\mathrm{Aa}}$ & $(1837 \pm 0.06)^{\mathrm{Aa}}$ & $(5159 \pm 0.07)^{\mathrm{Aa}}$ & $(5141 \pm 0.03)^{\mathrm{Aa}}$ \\
\hline & 7 & $(1716 \pm 0.02)^{\mathrm{Aa}}$ & $(1705 \pm 0.05)^{\mathrm{Ba}}$ & $(1494 \pm 0.07)^{\mathrm{Aa}}$ & $(1468 \pm 0.02)^{\mathrm{Bb}}$ & $(1838 \pm 0.07)^{\mathrm{Aa}}$ & $(1817 \pm 0.02)^{\mathrm{BC}}$ & $(5048 \pm 0.02)^{\mathrm{Aa}}$ & $(4990 \pm 0.03)^{\mathrm{Bb}}$ \\
\hline & 14 & $(1709 \pm 0.07)^{\mathrm{Aa}}$ & $(1689 \pm 0.01)^{\mathrm{Cb}}$ & $(1450 \pm 0.01)^{\mathrm{Aa}}$ & $(1448 \pm 0.09)^{\mathrm{BCa}}$ & $(1787 \pm 0.02)^{\mathrm{Aa}}$ & $(1735 \pm 0.06)^{\mathrm{cc}}$ & $(4946 \pm 0.02)^{\mathrm{Aa}}$ & $(4872 \pm 0.02)^{\mathrm{cb}}$ \\
\hline & 21 & $(1689 \pm 0.01)^{\mathrm{Aa}}$ & $(1659 \pm 0.07)^{\mathrm{Da}}$ & $(1451 \pm 0.02)^{\mathrm{Aa}}$ & $(1425 \pm 0.06)^{\mathrm{cb}}$ & $(1751 \pm 0.05)^{\mathrm{Aa}}$ & $(1717 \pm 0.02)^{\mathrm{CDb}}$ & $(4891 \pm 0.02)^{\mathrm{Aa}}$ & $(4801 \pm 0.05)^{\mathrm{Db}}$ \\
\hline & 28 & $(1622 \pm 0.02)^{\mathrm{Ab}}$ & $(1609 \pm 0.02)^{\mathrm{Eb}}$ & $(1368 \pm 0.04)^{\mathrm{Aa}}$ & $(1378 \pm 0.07)^{\mathrm{Da}}$ & $(1747 \pm 0.04)^{\mathrm{Aa}}$ & $(1699 \pm 0.06)^{\mathrm{Db}}$ & $(4737 \pm 0.03)^{\mathrm{Aa}}$ & $(4686 \pm 0.10)^{\mathrm{Ea}}$ \\
\hline
\end{tabular}

Mean values in the same column with different capital letters are significantly different $(p<0.05)$ between storage durations. Mean values in the same row with different lower-case letters are significantly different $(p<0.05)$ between different temperatures. Results are expressed as mean value \pm standard deviation $(N=3)$ 
radical process of sterol autoxidation (39). The exposure of salad dressing to the air and the addition of water during preparation may have contributed to the loss of phytosterols in this study.

Higher content of phytosterols was found in the dressing with $30 \%$ cocoa butter at the different storage temperatures than in commercial and salad dressing with $0 \%$ cocoa butter (Table 4). Higher content of phytosterols in cocoa butter than in soybean oil probably contributed to higher phytosterol content in the salad dressing with $30 \%$ cocoa butter than in commercial and dressing with $0 \%$ cocoa butter. The blending of the oils resulted in high content of phytosterols. Phytosterol oxidation was faster in the emulsion than in the oil. Interfacial tension measurement showed that phytosterols have a high degree of surface activity that allows them to move to the oil-water interface of the emulsion droplets (40).

\section{Antioxidant activity in salad dressings}

Table 5 shows that during 28 days of storage at $4{ }^{\circ} \mathrm{C}$, the antioxidant activity of commercial salad dressing (48.8 to 44.16 $\%)$ decreased significantly $(p<0.05)$. Similar was observed for salad dressings with $0 \%$ (44.7 to $22.3 \%$ ) and $30 \%$ cocoa butter (52.79 to $47.4 \%)$. During storage, the deterioration of the phenolic compounds probably resulted in decreased antioxidant activity. The antioxidant content also decreased as the temperature increased. Gazzani et al. (41), who compared the effect of different temperatures $\left(2,25\right.$ and $\left.102^{\circ} \mathrm{C}\right)$, stated that a higher temperature may affect the antioxidant activity of vegetable samples. The highest antioxidant content was found in salad dressing with $30 \%$ cocoa butter compared to commercial and salad dressing with $0 \%$ cocoa butter at different temperatures. The highest antioxidant activity obtained in the salad dressing with $30 \%$ cocoa butter might be due to the presence of cocoa butter mixed with soybean oil instead of soybean oil alone. Our preliminary results indicated that cocoa butter contained a high amount of antioxidants ( $84 \%$ ) compared to soybean oil (46.39\%). Thus, blending the cocoa butter with soybean oil proved to increase the level of antioxidants in the salad dressing compared to the formulation with soybean oil alone.

High phenolic content contributes to high antioxidant activity. Table 5 shows changes in total phenolic content and degradation during storage for 28 days at 4 and $30^{\circ} \mathrm{C}$. Significantly, the highest phenolic content at 4 and $30^{\circ} \mathrm{C}$ was obtained in the salad dressing with $30 \%$ cocoa butter $(7.41$ to $6.56 \mathrm{mg} / 100$ g) compared to commercial (5.87 to $3.27 \mathrm{mg} / 100 \mathrm{~g}$ ) and salad dressing with $0 \%$ cocoa butter ( 4.77 to $3.45 \mathrm{mg} / 100 \mathrm{~g}$ ) due to the addition of cocoa butter, which has high phenolic content ( $28.77 \mathrm{mg} / 100 \mathrm{~g}$ ) compared to soybean oil $(4.70 \mathrm{mg} / 100 \mathrm{~g})$. Nevertheless, Abramovič et al. (42) observed the reduction of polar phenolic content in the Camelina sativa oil after storage at 50 and $65^{\circ} \mathrm{C}$ for 44 days, when the content of phenolics in the oil started to decrease after 7 days of storage. Okogeri and Tasioula-Margari (43) also reported that during storage of virgin olive oil under diffused light at 6 and $18^{\circ} \mathrm{C}$ for 6 months, about $60 \%$ reduction of total phenols occurred, indicating their rapid degradation. There was a decrease of phenolics in commercial salad dressing and all salad dressing with cocoa butter as the temperature of storage increased (Table 5). A relationship study between oxidation and antioxidant activity in krill oil by Lu et al. (44) revealed that the antioxidant activity was not stable at high temperatures $\left(20\right.$ and $40^{\circ} \mathrm{C}$ ) and the presence of both tocopherol and phospholipids or synergism between them might also contribute to the oxidative stability of the oil. It is clearly demonstrated that the increase of temperature led to an increase of lipid oxidation in oil.

Table 5. DPPH assay and total phenolic content in different salad dressings during storage at 4 and $30^{\circ} \mathrm{C}$

\begin{tabular}{|c|c|c|c|c|c|}
\hline \multirow{3}{*}{$\begin{array}{l}\text { Type of salad } \\
\text { dressing }\end{array}$} & \multirow{3}{*}{$\frac{t \text { (storage) }}{\text { day }}$} & \multicolumn{4}{|c|}{ Temperature $/{ }^{\circ} \mathrm{C}$} \\
\hline & & 4 & 30 & 4 & 30 \\
\hline & & \multicolumn{2}{|c|}{$w(\mathrm{DPPH}) / \%$} & \multicolumn{2}{|c|}{$w($ total phenolics $) /(\mathrm{mg} / 100 \mathrm{~g})$} \\
\hline \multirow{5}{*}{ Commercial } & 0 & $(48.8 \pm 0.2)^{\mathrm{Aa}}$ & $(48.5 \pm 0.2)^{\mathrm{Aa}}$ & $(5.87 \pm 0.01)^{\mathrm{Aa}}$ & $(5.65 \pm 0.01)^{\mathrm{Aa}}$ \\
\hline & 7 & $(47.39 \pm 0.06)^{\mathrm{Ba}}$ & $(46.3 \pm 0.2)^{B C}$ & $(5.34 \pm 0.01)^{\mathrm{Ba}}$ & $(4.65 \pm 0.01)^{\mathrm{BC}}$ \\
\hline & 14 & $(46.8 \pm 0.1)^{\mathrm{ca}}$ & $(45.3 \pm 0.1)^{\mathrm{cc}}$ & $(4.84 \pm 0.01)^{\mathrm{Ca}}$ & $(4.15 \pm 0.01)^{\mathrm{cc}}$ \\
\hline & 21 & $(46.4 \pm 0.1)^{\mathrm{Da}}$ & $(44.8 \pm 0.2)^{\mathrm{DC}}$ & $(4.22 \pm 0.04)^{\mathrm{Da}}$ & $(3.57 \pm 0.03)^{D C}$ \\
\hline & 28 & $(45.89 \pm 0.03)^{\mathrm{Ea}}$ & $(44.16 \pm 0.09)^{\mathrm{Ec}}$ & $(3.5 \pm 0.1)^{\mathrm{Еa}}$ & $(3.27 \pm 0.01)^{\mathrm{EC}}$ \\
\hline \multirow{5}{*}{$\begin{array}{l}0 \% \text { cocoa butter } \\
\text { (control) }\end{array}$} & 0 & $(44.7 \pm 0.1)^{\mathrm{Aa}}$ & $(43.3 \pm 0.2)^{\mathrm{Aa}}$ & $(4.77 \pm 0.01)^{\mathrm{Aa}}$ & $(4.56 \pm 0.01)^{\mathrm{AC}}$ \\
\hline & 7 & $(43.8 \pm 0.4)^{\mathrm{Ba}}$ & $(35.8 \pm 0.6)^{B C}$ & $(4.26 \pm 0.02)^{\mathrm{Ba}}$ & $(4.08 \pm 0.02)^{\mathrm{BC}}$ \\
\hline & 14 & $(41.43 \pm 0.06)^{\mathrm{Ca}}$ & $(30.34 \pm 0.05)^{\mathrm{Cc}}$ & $(4.03 \pm 0.06)^{\mathrm{Ca}}$ & $(3.90 \pm 0.03)^{\mathrm{Cc}_{\mathrm{c}}}$ \\
\hline & 21 & $(39.7 \pm 0.2)^{\mathrm{Da}}$ & $(24.5 \pm 0.2)^{\mathrm{DC}}$ & $(3.70 \pm 0.01)^{\mathrm{Da}}$ & $(3.52 \pm 0.01)^{\mathrm{Db}}$ \\
\hline & 28 & $(38.3 \pm 0.6)^{\mathrm{Ea}}$ & $(22.3 \pm 0.2)^{\mathrm{Ec}}$ & $(3.64 \pm 0.02)^{\mathrm{Ea}}$ & $(3.45 \pm 0.02)^{\mathrm{EC}}$ \\
\hline \multirow{5}{*}{$30 \%$ cocoa butter } & 0 & $(52.79 \pm 0.01)^{\mathrm{Aa}}$ & $(52.2 \pm 0.5)^{\mathrm{Aa}}$ & $(7.41 \pm 0.01)^{\mathrm{Aa}}$ & $(7.4 \pm 0.1)^{\mathrm{Aa}}$ \\
\hline & 7 & $(51.92 \pm 0.07)^{\mathrm{Ba}}$ & $(50.7 \pm 0.4)^{\mathrm{Bb}}$ & $(7.39 \pm 0.01)^{\mathrm{Ba}}$ & $(7.00 \pm 0.03)^{\mathrm{Bb}}$ \\
\hline & 14 & $(51.42 \pm 0.03)^{\mathrm{Ca}}$ & $(49.7 \pm 0.2)^{c^{c c}}$ & $(7.07 \pm 0.01)^{\mathrm{Ca}}$ & $(6.76 \pm 0.01)^{\mathrm{cc}}$ \\
\hline & 21 & $(50.8 \pm 0.2)^{\mathrm{Da}}$ & $(48.7 \pm 0.5)^{\mathrm{Db}}$ & $(6.96 \pm 0.01)^{\mathrm{Da}}$ & $(6.71 \pm 0.01)^{\mathrm{Db}}$ \\
\hline & 28 & $(50.3 \pm 0.2)^{\mathrm{Ea}}$ & $(47.4 \pm 0.2)^{\mathrm{Ec}}$ & $(6.75 \pm 0.03)^{\mathrm{Ea}}$ & $(6.56 \pm 0.03)^{\mathrm{Ec}}$ \\
\hline
\end{tabular}

Mean values in the same column with different capital letters are significantly different $(p<0.05)$ between storage durations. Mean values in the same row with different lower-case letters are significantly different $(p<0.05)$ between different temperatures. Results are expressed as mean value \pm standard deviation $(N=3)$ 


\section{CONCLUSIONS}

An increase in temperature from 4 to $30^{\circ} \mathrm{C}$ after 28 days of storage significantly $(p<0.05)$ affected the physical parameters of control, salad dressing with $30 \%$ cocoa butter and commercial salad dressing (flow consistency index, flow behaviour index, apparent viscosity, iodine value, peroxide value and acid value). Emulsion stability test showed insignificant ( $p>0.05$ ) differences in all salad dressings at different storage temperatures. However, significantly $(p<0.05)$ low amount of phytosterols was observed after 28 days of storage at $30^{\circ} \mathrm{C}$ in all salad dressings. All salad dressings stored at refrigerated temperature $\left(4{ }^{\circ} \mathrm{C}\right)$ were able to resist the oxidation and loss of compounds compared to those stored at $30^{\circ} \mathrm{C}$. The DPPH, total phenolic and phytosterol contents also decreased as the temperature increased from 4 to $30^{\circ} \mathrm{C}$ during storage from 7 to 28 days. Thus, it was concluded that $4^{\circ} \mathrm{C}$ is a suitable temperature to keep the salad dressing even though the cloudiness of the dressing was higher than at $30^{\circ} \mathrm{C}$. Adequate storage temperature of salad dressing with cocoa butter is crucial for industrial application in order to maintain its high quality and preserve bioactive compounds in it during storage.

\section{ACKNOWLEDGEMENTS}

The authors are grateful for the financial support provided by IPS grant Universiti Putra Malaysia (UPM) under the project number GP-IPS/2013/9399841.

\section{CONFLICT OF INTEREST}

The authors declare that they have no conflict of interest.

\section{REFERENCES}

1. Ntanios F. Plant sterol-ester-enriched spreads as an example of a new functional food. Eur J Lipid Sci Technol. 2001;103(2):102-6.

https://doi.org/10.1002/1438-

9312(200102)103:2<102::AID-EJLT102>3.0.CO;2-A

2. Staphylakis K, Gegiou D. Free, esterified and glucosidic sterols in cocoa butter. Lipids. 1985;20(11):723-8.

https://doi.org/10.1007/BF02534394

3. AbuMweis SS, Barake R, Jones PJH. Plant sterols/stanols as cholesterol lowering agents: A meta-analysis of randomized controlled trials. Food Nutr Res. 2008;52: Artcle no. 1811. https://doi.org/10.3402/fnr.v52i0.1811

4. Ntanios FY, Homma Y, Ushiro S. A spread enriched with plant sterol-esters lowers blood cholesterol and lipoproteins without affecting vitamins $A$ and $E$ in normal and hypercholesterolemic Japanese men and women. J Nutr. 2002;132(12):36505. https://doi.org/10.1093/jn/132.12.3650

5. Diftis NG, Biliaderis CG, Kiosseoglou VD. Rheological properties and stability of model salad dressing emulsions prepared with a dry-heated soybean protein isolate-dextran mixture. Food Hydrocolloid. 2005;19(6):1025-31.

https://doi.org/10.1016/j.foodhyd.2005.01.003
6. Przybylski R, Zambiazi R, Li W. Kinetics of sterols changes during storage and frying of canola oils. Erina, Australia: The Regional Institute; 2014. Available from: http://www.regional. org.au/au/gcirc/1/349.htm.

7. Soupas L, Huikko L, Lampi AM, Piironen V. Oxidative stability of phytosterols in some food applications. Eur Food Res Technol. 2006;222(3-4):266-73.

https://doi.org/10.1007/s00217-005-0031-0

8. Jekel AA, Vaessen HAMG, Schothorst RC. Capillary gas-chromatographic method for determining non-derivatized sterols-some results for duplicate $24 \mathrm{~h}$ diet samples collected in 1994. Fresenius J Anal Chem. 1998;360(5):595-600.

https://doi.org/10.1007/s002160050764

9. Koh SP, Arifin N, Tan CP, Yusoff MSA, Long K, Idris NA, Lai OM. Rheological properties, oxidative stability and sensory evaluation of enzymatically synthesized medium- and long-chain triacylglycerol-based salad dressings. Eur J Lipid Sci Tech. 2008;110(12):1116-26.

https://doi.org/10.1002/ejlt.200800066

10. Hathcox AK, Beuchat LR, Doyle MP. Death of enterohemorrhagic Escherichia coli 0157:H7 in real mayonnaise and reduced-calorie mayonnaise dressing as influenced by initial population and storage temperature. Appl Environ Microbiol. 1995;61(12):4172-77.

11. HAAKE RheoWin 3 Software, v. 3.61.0004, Thermo Fisher Scientific, Waltham, MA, USA; 2012. Available from: http://www. rheowin.com/rheowin3.htm.

12. Mun S, Kim YL, Kang CG, Park KH, Shim JY, Kim YR. Development of reduced-fat mayonnaise using 4aGTase-modified rice starch and xanthan gum. Int J Biol Macromol. 2009; 44(5):400-7.

https://doi.org/10.1016/j.ijbiomac.2009.02.008

13. AOCS Method Cd 1d-92. lodine value of fats and oils, cyclohexane-acetic acid method. Urbana, IL, USA: American Oil Chemists' Society (AOCS); 1993.

14. AOCS Method Cd 8-53. Peroxide value, acetic acid-chloroform method. Urbana, IL, USA: American Oil Chemists'Society (AOCS); 1993.

15. AOCS Method Ca $5 a-40$. Free fatty acids in crude and refined fats and oils. Urbana, IL, USA: American Oil Chemists' Society (AOCS); 1993.

16. Careri M, Elviri L, Mangia A. Liquid chromatography-UV determination and liquid chromatography-atmospheric pressure chemical ionization mass spectrometric characterization of sitosterol and stigmasterol in soybean oil. J Chromatogr A. 2001;935(1-2):249-57.

https://doi.org/10.1016/S0021-9673(01)01079-2

17. Brand-Williams W, Cuvelier ME, Berset C. Use of a free radical method to evaluate antioxidant activity. LWT - Food Sci Technol. 1995;28(1):25-30.

https://doi.org/10.1016/S0023-6438(95)80008-5

18. Singleton VL, Rossi JA. Colorimetry of total phenolics with phosphomolybdic-phosphotungstic acid reagents. Am J Enol Vitic. 1965;16:144-58. 
19. Minitab ${ }^{\circledast} 16$ Statistical Software, Minitab Inc., State College, PA, USA; 2011. Available from: http://www.minitab.com.

20. Paredes MDC, Rao MA, Bourne MC. Rheological characterization of salad dressings. 1. Steady shear thixotropy and effect of temperature. J Texture Stud. 1988;19(3):247-58. https://doi.org/10.1111/j.1745-4603.1988.tb00940.x

21. Dimitreli G, Thomareis AS. Effect of temperature and chemical composition on processed cheese apparent viscosity. J Food Eng. 2004;64(2):265-71.

https://doi.org/10.1016/j.jfoodeng.2003.10.008

22. Darby R. Determining settling rates of particles. In: Darby $R$, editor. Chemical engineering fluid mechanics. New York, NY, USA: Marcel Dekker; 1996. pp. 107-12.

23. Bienvenue $\mathrm{R}$, Jiménez-Flores $\mathrm{H}$, Singh $\mathrm{H}$. Rheological properties of concentrated skim milk: importance of soluble minerals in the changes in viscosity during storage. J Dairy Sci. 2003; 86(12):3813-21.

https://doi.org/10.3168/jds.S0022-0302(03)73988-5

24. Ahmed J. Rheological behaviour and colour changes of ginger paste during storage. Int J Food Sci Tech. 2004;39(3):325-30. https://doi.org/10.1111/j.1365-2621.2004.00789.x

25. Leroux J, LangendorffV, Schick G, Vaishnav V, Mazoyer J. Emulsion stabilizing properties of pectin. Food Hydrocolloid. 2003; 17(4):455-62.

https://doi.org/10.1016/S0268-005X(03)00027-4

26. McClements DJ, editor. Food emulsions: Principles, practices and techniques. Boca Raton, FL, USA: CRC Press; 2005.

27. Abu Ghoush M, Samhouri M, Al-Holy M, Herald T. Formulation and fuzzy modeling of emulsion stability and viscosity of a gum-protein emulsifier in a model mayonnaise system. J Food Eng. 2008;84(2):348-57.

https://doi.org/10.1016/j.jfoodeng.2007.05.025

28. Liauw MY, Natan FA, Widiyanti P, Ikasari D, Indraswati N, Soetaredjo FE. Extraction of neem oil (Azadirachta indica A. Juss) using $n$-hexane and ethanol: studies of oil quality, kinetic and thermodynamic. ARPN J Eng Appl Sci. 2008;3(3):49-54.

29. Phuah ET, Beh BK, Lim CSY, Tang TK, Lee YY, Lai OM. Rheological properties, textural properties, and storage stability of palm kernel-based diacylglycerol-enriched mayonnaise. Eur J Lipid Sci Tech. 2016;118(2):185-94.

https://doi.org/10.1002/ejlt.201400586

30. Siddique YH, Ara G, Afzal M. Estimation of lipid peroxidation induced by hydrogen peroxide in cultured human lymphocytes. Dose-Response. 2012;10(1);1-10.

https://doi.org/10.2203/dose-response.10-002.siddique

31. Ramezani R. The effect of packaging materials and storage condition on the oxidative stability of refined sunflower oil. Food Sci Technol Res. 2004;10(3):350-4. https://doi.org/10.3136/fstr.10.350

32. Sengar G, Sharma HK, Kaur M. Effect of storage conditions on physico-chemical properties and fatty acid ratio, C18:2/C16:1 of blended fat. Int J Postharvest Technol Innov. 2014;4(1):81101.

https://doi.org/10.1504/IJPTI.2014.064167
33. Canakci M. The potential of restaurant waste lipids as biodiesel feedstocks. Bioresour Technol. 2007;98(1):183-90.

https://doi.org/10.1016/j.biortech.2005.11.022

34. Mittelbach $M$, Gangl S. Long storage stability of biodiesel made from rapeseed and used frying oil. J Am Oil Chem Soc. 2001;78(6):573-7.

https://doi.org/10.1007/s11746-001-0306-z

35. Khraisha YH. Retorting of oil shale followed by solvent extraction of spent shale: Experiment and kinetic analysis. Energy Source. 2000;22(4):347-55.

https://doi.org/10.1080/00908310050013947

36. Żyżelewicz D, Budryn G, Krysiak W, Oracz J, Nebesny E, Bojczuk M. Influence of roasting conditions on fatty acid composition and oxidative changes of cocoa butter extracted from cocoa bean of Forastero variety cultivated in Togo. Food Res Int. 2014;63(Part C):328-43.

https://doi.org/10.1016/j.foodres.2014.04.053

37. Osada K, Kodama T, Yamada K, Sugano M. Oxidation of cholesterol by heating. J Agric Food Chem. 1993;41(8):1198-202. https://doi.org/10.1021/jf00032a006

38. Nourooz-Zadeh J, Appelqvist LÅ. Isolation and quantitative determination of sterol oxides in plant-based foods: Soybean oil and wheat flour. J Am Oil Chem Soc. 1992;69(3):288-93. https://doi.org/10.1007/BF02635903

39. Maerker G, Nungesser EH, Bunick FJ. Reaction of cholesterol 5,6-epoxides with simulated gastric juice. Lipids. 1988;23(8): 761-5. https://doi.org/10.1007/BF02536218

40. Cercaci L, Rodriguez-Estrada MT, Lercker G, Decker EA. Phytosterol oxidation in oil-in-water emulsions and bulk oil. Food Chem. 2007;102(1):161-7. https://doi.org/10.1016/j.foodchem.2006.05.010

41. Gazzani G, Papetti A, Massolini G, Daglia M. Anti- and prooxidant activity of water soluble components of some common diet vegetables and the effect of thermal treatment. J Agric Food Chem. 1998;46(10):4118-22.

https://doi.org/10.1021/jf980300o

42. Abramovič H, Butinar B, Nikolič V. Changes occurring in phenolic content, tocopherol composition and oxidative stability of Camelina sativa oil during storage. Food Chem. 2007; 104(3):903-9.

https://doi.org/10.1016/j.foodchem.2006.12.044

43. Okogeri O, Tasioula-Margari M. Changes occuring in phenolic compounds and a-tocopherol of virgin olive oil during storage. J Agric Food Chem. 2002; 50(5):1077-80. https://doi.org/10.1021/jf010895e

44. Lu FSH, Bruheim I, Haugsgjerd BO, Jacobsen C. Effect of temperature towards lipid oxidation and non-enzymatic browning reactions in krill oil upon storage. Food Chem. 2014;157:398-407.

https://doi.org/10.1016/j.foodchem.2014.02.059 